\title{
Passion and Creativity - Together or Separately?
}

\author{
Beata Kunat \\ University of Bialystok, Poland \\ E-mail address: b.kunat@uwb.edu.pl
}

\section{ARTICLE INFO}

\section{Keywords:}

Passion

Creativity

Dualistic model of passion

Flow

Grit

\section{Article history:}

Received 12 April 2018

Received in revised form 05 May 2018

Accepted 14 June 2018

ISSN: 2354-0036

DOI: $10.1515 /$ ctra-2018-0004

\section{A B S TR A C T}

In this paper I will attempt to compare two categories of passion and creativity. I will try to answer the question: What has passion got in common with creativity? What is the common denominator and what is different? What is the role of passion in the creative process? Searching for the mechanism of passion and its components is necessary to discover its relation to creativity I will refer to passion psychology (Vallerand, 2015). The basis of my analysis will be the Dualistic Model of Passion (Vallerand et al., 2003; Vallerand 2008, 2010, 2015), the concept of Grit: The Power of Passion and Perserverance (Duckworth et al., 2007; Duckworth \& Quinn, 2009, Duckworth 2016) and the concept of Flow (Csíkszentmihályi, 1996). In the process of mapping the areas that connect passion with creativity I will refer to four ways of its understanding: creativity as a process, a personality trait complex, a product and the interaction between the creative individual and the context or environment. I will also refer in my comparisons to The four $C$ Model of Creativity (Kaufman \& Beghetto 2009).

\section{INTRODUCTION}

There are two categories that I set out to look into: passion and creativity. I will make an attempt to answer the questions: what has passion got in common with creativity? What is the common denominator and what is different? What is the role of passion in the creative process? Searching for the mechanims of passion and its components is necessary to discover its relation to creativity I will refer to passion psychology (Vallerand, 2015). I will base my analysis on the The dualistic Model of Passion (Vallerand et. al., 2003; Vallerand 2008, 2010, 2015), the concept of Grit: The power of Passion and Perseverance (Duckworth et al., 2007; Duckworth \& Quinn, 2009; Duckworth, 2016) and the concept of Flow (Csíkszentmihályi, 1996). In the process of recognition of the areas associating passion with creativity I will refer to the four ways of understanding creativity: creativity as a process, a group of personality traits, a product and the interaction between the crea- 
tive individual and the context of environment (Beghetto \& Kaufman, 2007, 2009; Runco, 2003; Plucker, et al., 2004). In my comparative analysis I will also refer to The Four C Model of Creativity (Kaufman \& Beghetto, 2009).

\section{What is passion? Definitions - concepts - models}

Various meanings of passion can be found in scientific publications. Depending on the field of science, the researchers interested in passion point to its multiple contexts (Kunat, 2015a). Most often passion is understood as a force behind an action, it is defined as "something" that drives us, a steering factor. Passion is associated with motivation (Frijda et al., 1991; Moeller, 2014). It is considered in the context of human emotions (Csíkszentmihályi, 1996; Tokarz, 2005; Fisher \& Amabile, 2009; Fredricks et al., 2010; StLouis, Vallerand, 2015). Scientists stress that positive emotions make the creative process easier (Kaufman, 2003; Lubart \& Getz, 1997; St-Louis, Vallerand, 2015). Positive emotions open up human beings and make them more creative (Fredrickson, 2001). Among the positive emotions associated with the creative process besides surprise and amazement, passion is also singled out, as having a heuristic function, evaluation and being an energetic force (Tokarz, 2005). Taking into consideration all of the above, passion can be understood as the source of pro-creative emotions in the context of human creativity.

Passion also has a place in the theoretical models of human abilities (Popek, 2015). It is understood within the context of attributes, when researchers point to it as forming the attributes of a person (Kaufman \& Gregoire, 2015; Day, 2004). Passion is seen as one of the attributes of a creative person (Amabile \& Fisher, 2009; Csíkszentmihályi, 2015). Kaufman and Gregoire identify passion as one of ten attributes and habits (alongside imaginative play, daydreaming, solitude, intuition, openness to experience, mindfulness, sensitivity, turning adversity into advantage, thinking differently) of highly creative people (Kaufman \& Gregoire, 2015). In the analysis of passion categories as a subject attribute relating to particular individuals (i.e. a passionate teacher) it is worth noting the pro-active qualities of passion (Phelps \& Benson, 2012; Day, 2004; Fried, 2001). Passion manifests through the dedication and enthusiasm of a person. In people acting with passion there lay dormant unfathomable layers of intellectual and emotional energy (Day, 2004; Kunat, 2017). Passion is analysed in relation to variously defined human creativity (Amabile \& Fisher, 2009, Averill, 2002; Csikszentmihalyi, 1996; Goldberg, 1986; Tokarz 2005; Kaufman \& Gregoire, 2015; Kunat 2015b; Lafrenière, St-Louis, Vallerand \& Donahue 2012; Grohman et al., 2017).

In looking for the mechanisms and components of passion which are necessary to reveal its relationship toward creativity I will refer to the two most often scientifically explored definitions of passion. The first understanding of passion which is of interest to the 
present discussion comes from the assumptions of the psychology of passion of Robert Vallerand (2015). Based on empirical data he creates a multidimensional definition of passion (Vallerand et al., 2003). Passion "can be seen as strong inclination toward a specific object, activity, concept or person that one loves (or at least strongly likes), highly values, invests time and energy in on a regular basis, and that is part of one's identity" (Vallerand, 2015, p. 33). The above definition appears in The Dualistic Model of Passion (Vallerand et al., 2003; Vallerand 2008, 2010, 2015). The second approach to passion that constitutes an important context for my analysis comes from the concept Grit: The Power of Passion and Perseverance (Duckworth et al., 2007; Duckworth, 2016). In this case, passion and persistence as defined by the construct of grit (Duckworth et al., 2007; Duckworth, 2016). Grit is defined as a trait reflecting high levels of passion and persistence in relation to long-term goals (Duckworth et al., 2007).

\section{What is creativity? Contexts - approaches - levels}

In the process of a comparative analysis of passion and creativity I will refer to various ways of understanding creativity. Creativity in the scientific literature is usually defined through reference to the four cognitive categories: process, personality traits, product and the interaction between the creative individual and the context or environment (Runco, 2003; Plucker et al., 2004).

Creativity is understood as a process generating new, original and valuable products - ideas, concepts and solutions (Szmidt, 2007, 2010). Creativity is the production of unique, novelty and useful/valuable products, services, processes or procedures (Hennessey \& Amabile, 2010; Peterson \& Seligman, 2004; Plucker et al., 2004; Sternberg \& Lubart, 1996; Amabile, 1996). It is also seen as a group of interconnected and codependent human features that is human abilities, a creative approach, openness and freedom (Karwowski, 2010). Creativity is then associated with the character of a person, their sensitivity to problems, openness, motivation and cognitive competences for action creative abilities (Karwowski, 2009). In the context of personal concepts of creativity, the concept of creativity is associated with its creative potential (Runco, 2004, 2016; Barbot, Besançon \& Lubart, 2015; Silvia, Christensen, \& Cotter, 2016). Creativity is analysed here from the perspective of various levels. Polish researchers of creativity single out recreational creativity, amateur, master, transgressive (Szmidt, 2013b); fluid, crystallized, mature, exceptional (Nęcka, 2002). According to The Four C Model of Creativity (Kaufman \& Beghetto, 2009) we can distinguish four levels of creativity: potential creativity ("mini C"), everyday creativity ("Iittle C"), professional creativity ("pro C"), exceptional/ genius creativity ("big C"). 


\section{The Dualistic Model of Passion and Creativity}

The theoretical foundation in research for areas that relate passion and various understandings of creativity will be The Dualistic Model of Passion (Vallerand et al., 2003; Vallerand 2008, 2010, 2015). Vallerand and his co-workers (2003) created The Dualistic Model of Passion (Vallerand,et al., 2003; Vallerand, 2008, 2015) based on Selfdetermination Theory - SDT (Ryan \& Deci, 2000). According to this model, passion is a strong need for action in a specific direction, propensity for activity that a person likes and considers important, in which a person invests their time and energy in order to satisfy their need for autonomy, competence and integrity (Vallerand et al., 2003). Autonomy refers to experiencing one's own integrity and freedom of action and expresses it in a desire to initiate new activities with no external influence (promises, rewards) (Ryan \& Brown, 2003). Autonomy makes a person take part in activity caused by internal motivation, which means that they search for novelty and challenges, develops and hones their abilities, explores and learns (Franken, 2005). The need for competence refers to the feeling of being effective and useful. On the other hand, the need to relate to others refers to the desire of being with others and the sense of belonging to a group, which is supported by society by acceptance and understanding (Ryan \& Brown, 2003). A passionate activity is an indication of human identity (Vallerand et al., 2008). According to the dualistic model of passion there are two kinds of passion: harmonious passion (HP) and obsessive passion (OP). Hence, passion can have both positive as well as negative significance on the life of a person and their creativity (Parastatidou et al., 2012). Harmonious passion is associated with an autonomous internalization of activity - the object of passion with which a person identifies. Internalization takes place when a person naturally accepts their activity as something significant, life valid and possesses autotelic motivation for action. A person with a harmonious passion does not experience uncontrolled desire to engage in their passion but rather chooses freely, engages in various activities, but the passion does not burden them, it exist in harmony with other aspects of life hence it is associated with positive experiences (Hodgins \& Knee, 2002). That is why people of harmonious passion are able to focus fully on their task (focus, satisfaction, lack of conflict between passion and other aspects of life). They can control their actions and decide when to engage in activities they are passionate about (Vallerand, 2008). The harmonious passion creates positive environment for experiencing positive emotions (Mageau \& Vallerand, 2007; Mageau et al., 2005; Philipp et al., 2010, Philippe et al., 2009; Vallerand et al., 2003; Vallerand et al., 2006; Vallerand et al., 2008; Vallerand et al., 2010). People with an obsessive passion can experience uncontrolled desire for action, not tak- 
ing into account the consequences of their engagement (the passion controls their life). The obsessive passion begets negative emotions, conflicts, frustrations - can lead to exhaustion and even health problems or can spoil relations with others (Philippe et al., 2009; Philippe et al., 2010; Rousseau \& Vallerand, 2008; Vallerand et al., 2006; Vallerand et al., 2007; Vallerand et al., 2010).

A standardized tool for analysing both harmonious and obsessive passion is The Passion Scale (Vallerand et al., 2003; Vallerand 2008, 2015), which is now a basis for a number of empirical studies of passion related to various types of human activities (Kunat, 2015c).

The Dualistic Model of Passion has been the basis of research aimed at recognizing relations between passion and creativity (i.e. Lafrenière, et al., 2012; Liu, Chen, \& Yao, 2011; Luh \& Lu, 2012; Shi, 2012; St-Louis \& Vallerand, 2015). Through application of The Passion Scale together with other tools, the connections of passion with human creativity related to a group of personality features, creative process, creative conditions and creative achievements were searched for. It was attempted to establish what type of passion, harmonious (HP) or obsessive (OP) favours creativity in various areas of life. Research into the relation between passion and creativity referred to both an egalitarian and exclusive understanding of creativity. Passion was applied to the various levels of creativity: potential everyday creativity, professional creativity and outstanding/genius creativity.

\section{Passion and creative process}

Vallerand's concept of passion has been a basis for establishing the role of harmonious passion (HP) and obsessive passion (OP) and of emotions in the creative process of artists (St-Louis \& Ballerand 2015; Vallerand 2015). The research shows that artists who have harmonious passion engage in the creative process of their own free will. Artists who have obsessive passion experience an uncontrolled urge to engage in activity which can have both positive and negative consequences for their creative activities. The research attempted to establish the role of emotions and passion during creative processes that were successful. The first phase of the research focused on the positive emotions experienced by the artists at each stage of their creative process. The second phase evaluated the negative emotions of the artists exhibited during the creative process. The results demonstrated that positive emotions facilitate creativity. Negative emotions were almost absent in the course of a successful creative process. The research shows that during the various stages of a successful creative process, artists characterised by harmonious passion experience more positive emotions than those who have obsessive 
passions. Whereas positive emotions provide more flexibility and cognitive energy leading to greater creativity and perseverance in the creative process, experiencing negative emotions, especially those of a high level of activation is very often toxic for the creative process and can diminish creativity (Baas et al., 2008; Baas et al., 2012). The researchers conclude that the artists with OP can experience lower levels of creativity than artists with HP due to high levels of experiencing negative emotions (St-Louis \& Vallerand 2015). Using The Passion Scale for painting showed that even professional painters with twenty years of experience whose profession demonstrates their high level of creativity experience passion in this respect (Lafrenière, St-Louis, Vallerand, \& Donahue, 2012). Referring to The Four C Model of Creativity (Kaufman \& Beghetto, 2009) it is possible to say that in the case of the presented research results, passion is the source of professional creativity (pro C) and outstanding creativity (big C).

\section{Passion and the creative potential of a human being}

Research based on the dualistic passion model shows that harmonious passion can be the source of everyday creativity ("little C") and potential creativity ("mini C"). The research shows that HP motivates creativity in the work environment (Liu, Chen \& Yao, 2011). Research conducted in Chinese businesses (Research 1, N = 856; Research 3, $N=525$ ) showed that the harmonious passion of the employees fostered their creativity enabling them to create new and potentially useful ideas. The harmonious passion became a motivational factor that referred to autonomous internalization of professional activities making them a part of their identity. Other research demonstrated that experiencing harmonious professional passion is positively correlated with undertaking positive actions (Shi 2012). The study proposed a model of two types of work passion, harmonious and obsessive passion, to employees' innovative behaviour, via the mediating mechanism of cognitive absorption and organization-based self-esteem (OBSE). Based on research conducted among 228 employees in 19 Chinese companies it was concluded that employees with harmonious passion exhibit more innovative behaviours.

\section{Passion and creative achievements}

Research using The Passion Scale for design and self report of creativity achievement showed that HP is correlated with creativity (Luh \& Lu, 2012). The aim of the research was to establish a correlation between passion and cognitive style together with creative achievements in design. Based on research among 276 design students it was demonstrated that harmonious passion is positively associated with creative achievements. Experiencing obsessive passion by the students had no connection with their creativity. The research shows that harmonious passion plays an intermediary role between inno- 
vating cognitive style and creative achievements. The connection of harmonious passion among thespian art students with their creativity is also demonstrated by other research (Vallerand et al., 2007).

\section{The benefits of harmonious passion and creativity and the quality of human life}

The area that connects passion with human creativity is undoubtedly an area of benefits available to those who seek the sense of life. Both passion and creativity convey valuable potential. The psychological research has shown that harmonious passion is connected with positive emotions and an increase in the psychological welfare of a person, making them more effective in their endeavours (Ballerandet al., 2003). Harmonious passion facilitates the establishment of positive social interactions (Philippe et al., 2010). Researchers of creative phenomena point to the multidimensional significance of everyday creativity. Psychological research shows that the creative activity of humans supports their subjective welfare and is connected with life satisfaction, creativity has an extraordinary potential for progress, and is a resource that can improve the quality of human life (Modrzejewska-Świgulska, 2013, 2015; Szmidt, 2013a). The creative approach of a person is recognized by representatives of positive psychology as one that fosters happiness, realizing an individual's potential, autonomy, meaningfulness and self appreciation (Seligman, 2002; Csíkszentmihályi, 1996). From the perspective of an everyday creativity concept, it appears to bring about positive changes in the life of a human being, enabling effective solutions for everyday personal and professional problems and fostering personal growth (Modrzejewska-Śmigulska, 2013, 2015). Both passion and creativity are connected with a constant search for contentment and satisfaction in life. The research suggests that experiencing harmonious passion adds to well-being and welfare (Rousseau \& Vallerand, 2008). The research also points to a correlation between experiencing passion and the involvement of humans. People experiencing harmonious passion in various areas of activity are able to engage more fully in a given activity (Mageau \& Vallerand, 2007), are able to focus better on the task (Belanger et al., 2013a; Belanger et al., 2013b) and they are more effective (Vallerand et al., 2007, Vallerand et al., 2010). Harmonious passion evokes positive emotions and helps to increase the feeling of contentment (Philippe et al., 2010; Philippe, Vallerand, \& Lavigne, 2009; Rousseau \& Vallerand, 2008; Vallerand et al., 2003; Vallerand et al. 2006).

\section{Grit: The Power of Passion and Perseverance vs Creativity}

Another concept that is fundamental to my search for a correlation between passion and creativity is the concept of Grit (Duckworth et al., 2007; Duckworth, 2016). Grit is defined as a train reflecting high levels of perseverance and passion for long-term goals (Duckworth et al., 2007). A standardized scale to measure grit - the Grit Scale 
(Duckworth et al., 2007; Duckworth \& Quinn, 2009) is used to examine the correlation of grit with various phenomena (Eskreis-Winkleret al., 2014; Von Culin, Tsukayama \& Duckworth, 2014; Salles, Cohen \& Mueller, 2014). After applying the Grit Scale together with other tools, it was possible to look into the correlation of passion and persistence with creative achievement in terms of everyday creative behaviour (Grohman et al., 2017). The primary aim of the current investigation was to examine the incremental validity of two assessments of passion and persistence for creativity above the Big Five: personality traits: extraversion, agreeableness, conscientiousness, neuroticism, openness (Grohman et al., 2017 , p. 3). There were three tests carried out. The first was performed on 131 participants enrolled at the University of North Carolina at Greensboro. The eight-item subscales of the short Grit Scale were used (Duckworth \& Quinn, 2009) together with the Creative Achievement Questionnaire (CAQ; Carson et al., 2005). The research shows that the grit facets of passion of interests and persistence did not correlate with creative achievement. The second test was performed among 325 students from the University of Texas at Dallas. The 12-item version of the grit scale (Duckworth et al., 2007), the Creative Achievement Questionnaire (CAQ; Carson et al., 2005) and the Creativity Life-Space Scales (Ivcevic \& Mayer, 2009) were used in this study. The results showed that the grit facets of passion/consistency of interests and perseverance did not correlate with the creativity measures. In the third test 215 students took part at a private high school in the Northeast. Again the 12-item version of the grit scale was used (Duckworth et al., 2007) and teacher nominations of passion and persistence predicted creativity were referred to. The results indicated that the grit facet of passion/consistency of interests was not significantly correlated with teacher-nominated passion (Grohman, et al., 2017).

\section{Passion and "Flow"}

In looking for the pro-creative mechanics of passion, it is important to analyse them in the context of a concept of flow (Csíkszentmihályi, 1996). Csíkszentmihályi has contributed a notion of flow that suggests creative flow as a sense of optimal engagement in a task. In a state of flow, the learner's emotions are positive and energised and fully aligned to the task at hand. The research shows that harmonious passions are related to higher cognitive states of flow (Vallerand, 2010) and these states are most adapted to selfregulation. "Flow" is understood as a peak experience or optimal condition in which a person becomes very involved in an activity and experiences a focused effort and full control. This is a state between satisfaction and euphoria, evoked by a full commitment to a given activity; at such moments we feel elation, we also feel winged and deep contentment (Csikszentmihalyi, 1996). The author emphasises the importance of satisfying 
events in the life of a person which he defines as those that make us step beyond what is planned and achieve something unexpected. Satisfaction, he adds, is an experience that makes us grow, giving us a sense of novelty and achievement (Csikszentmihalyi, 1996). Passion, according to him, is one of the eight components of satisfaction. Satisfaction occurs when a person: undertakes tasks they are able to accomplish; is focused on activities; when the task clearly defines the goals and gives prompt feedback; and when a person has a passion, acts in a state of deep involvement that lacks an element of a excessive effort that eliminates the problems and concerns of everyday life from the person's awareness. Experiences that give satisfaction give, at the same time, a sense of control over one's own activities, anxiety and overthinking, and the sense of passage of time is altered too (Csikszentmihalyi, 1996). In relating flow to passion, it can be observed that they are different phenomena (Montijo \& Mouton, 2016). It has been demonstrated that flow is the result of passion and that people with passion for action more often experience the flow (Vallerand et al., 2003). Flow does not lead to passion (Levigne, Forest, \& Crevier-Braud, 2012).

\section{CONCLUSIONS}

The literature on the subject shows that passion and creativity have multiple meanings and as such are difficult to grasp and cognitively are very interesting. There are a number of concepts of passion and creativity. Passion and creativity are categories that are intensely cognitively exploited. Both can be expanded. Passion is a process that covers three stages: selection of the activity of interest, the object of the activity, personal evaluation of the activity and internalization of a passionate activity as an element of a person's identity (Vallerand et al., 2003). Analysis of these stages shows that there can occur a sort of coupling between passion and human creativity. Passion can be a source of human creativity, which itself can also be a platform for searching and developing passion in oneself. Moreover, both terms passion and creativity are "overused" in the contemporary public debate. In the Polish social space they are often treated as slogans for promoting various endeavours, projects, educational programmes, competitions. However, looking more closely at the proposals for some initiatives called "School with passion", "Creative school", "Losing weight with passion", "Creative books" etc. it turns out, that they are concerned with carrying out typical actions which do not display any traits of passion or creativity, novelty, nor are they genuine. Passion and creativity are there as a tool to attract attention because being a creative person or an institution is "cool".

The connection between passion and creativity cannot be unequivocally established on the basis of research reports (i.e. Grohman et al., 2017; Lafrenière et al., 2012; 
Liu, Chen \& Yao, 2011; Luh \& Lu, 2012; Shi, 2012; St-Louis \& Vallerand, 2015). The effect of passion on the creative process alters depending on the accepted definition of passion and its type. Correlations of passion and creativity also alter depending on the assumed understanding of creativity and its levels.

In the case of research based on Vallerand's Dualistic Model of Passion which aimed to recognize a correlation of passion with creativity (i.e. Lafrenière, et al., 2012; Liu, Chen, \& Yao, 2011; Luh, \& Lu, 2012; Shi, 2012; St-Louis, \& Vallerand, 2015) it was possible to establish a positive correlation between harmonious passion and creativity. There was no occurrence, however, of a positive correlation of obsessive passion with creativity. The research suggests that harmonious passion facilitates creativity seen as both a person's talent, process and the work. It is a factor that triggers innovation, new ideas and has a positive effect on the creative process. The analysed research dealing with passion and creativity referred to both an egalitarian and exclusive approach to creativity. In relation to The Four C Model of Creativity (Kaufman \& Beghetto, 2009) it is valid to say that harmonious passion triggers various levels of creativity; potential creativity ("mini C"), everyday creativity ("little C"), professional creativity ("pro C") and outstanding creativity ("big C"). The elements that connect passion with human creativity are the benefits that a person gains. The research demonstrates that harmonious passion triggers positive emotions that make the creative process easier (St-Louis \& Vallerand, 2015; Vallerand, 2015).

On the basis of an analysis (Grohman, et al., 2017) where the theoretical basis was the concept of Grit: The Power of Passion and Perseverance (Duckworth et al., 2007; Duckworth, 2016) it is possible to deduce that passion defined as a grit element does not correlate with creative achievement in terms of everyday creative behaviour. The research shows that passion is not a predictor of creativity on the "little C" level.

Calling upon the concept of Flow (Csíkszentmihályi, 1996) it has been demonstrated that passion does lead to flow, while flow does not lead to passion (Levigne, Forest \& Crevier-Braud, 2012; Vallerand et al., 2003).

Despite the research that has been undertaken into the relationship between passion and creativity there remain many unanswered questions. It is important to determine the functioning of various elements of passion, its components that may stimulate or hinder variously defined human creativity both in terms of an egalitarian and exclusive understanding of creativity. 


\section{REFERENCES}

Amabile, T. M. (1996). Creativity in context. Boulder, CO: Westview Press.

Amabile, T. M., \& Fisher, C. M. (2009). Stimulate creativity by fueling passion.

In E. A. Locke (Ed.), Blackwell handbook of principles of organizational behavior (2nd Ed.) (pp. 481-498). London: Wiley-Blackwell.

Averill, R. J. (2002). Emotional creativity: Toward "spiritualizing the passions".

In C. R. Snyder, \& S. J. Lopez (Eds.), Handbook of positive psychology (pp. 172-185). New York: Oxford University Press.

Baas, M., De Dreu, C. K. W., \& Nijstad, B. A. (2008). A meta-analysis of 25 years of research on mood and creativity: Hedonic tone, activation, or regulatory focus? Psychological Bulletin, 134, 739-756.

Baas, M., De Dreu, C. K. W., \& Nijstad, B. A. (2012). Emotions that associate with uncertainty lead to structured ideation. Emotion, 12, 1004-1014.

Barbot, B., Besançon, M., \& Lubart, T. I. (2015). Creative potential in educational settings: Its nature, measure, and nurture. Education, 43, 371-381. doi: 10.1080/ 03004279.2015 .1020643

Belanger, J. J., Lafreniere, M. K., Vallerand, R. J., \& Kruglanski, A. W. (2013a). When passion makes the heart grow colder: The role of passion in alternative goal suppression. Journal of Personality and Social Psychology, 104, 126-147. doi: 10.1037/a0029679

Belanger, J. J., Lafreniere, M. K., Vallerand, R. J., \& Kruglanski, A. W. (2013b). Driven by fear: The effect of success and failure information on passionate individuals' performance. Journal of Personality and Social Psychology, 104, 180-195. doi: 10.1037/ a0029585

Carson, S. H., Peterson, J. B., \& Higgins, D. M. (2005). Reliability, validity, and factor structure of the Creative Achievement Questionnaire. Creativity Research Journal, 17, 37-50. http://dx.doi.org/10.1207/ s15326934crj1701_4

Csíkszentmihályi, M. (1996). Creativity: Flow and the psychology of discovery and invention. New York, NY: Harper Collins Publishers.

Day, Ch. (2004). A Passion for Teaching. London: Routledge.

Duckworth, A. L., \& Quinn, P. D. (2009). Development and validation of the Short Grit Scale (Grit-S). Journal of Personality Assessment, 91, 166-174.

Duckworth, A. L., (2016). Grit: The Power of Passion and Perseverance. New York, NY, US: Scribner/Simon \& Schuster.

Duckworth, A. L., Peterson, C., Matthews, M. D., \& Kelly, D. R. (2007). Grit: Perseverance and passion for long-term goals. Journal of Personality and Social Psychology, 92, 1087-1101. http://dx.doi.org/10.1037/ 0022-3514.92.6.1087 
Eskreis-Winkler, L., Shulman, E.P., Beal, S.A., \& Duckworth, A.L. (2014). The grit effect: Predicting retention in the military, the workplace, school and marriage. Frontiers in Psychology, 5, 36.

Fisher, C. M., \& Amabile, T. (2009). Creativity, organization and improvisation. In T. Rickards, M. A. Runco, \& S. Moger (Eds.), The Routledge companion to creativity (pp. 13-24). Oxford, UK: Routledge.

Franken, R. E. (2005). Psychologia motywacji [Psychology of motivation].Trans. M. Przylipiak. Gdańsk: GWP.

Fredricks, J. A., Alfeld, C., \& Eccles, J. S. (2010). Developing and fostering passions in academic and nonacademic domains. Gifted Child Quarterly, 54(1), 18-30. doi:10.1177/0016986209352683

Fredrickson, B. L. (2001). The role of positive emotions in positive psychology: The broaden-and-build theory of positive emotions. American Psychologist, 56(3), 218-226.

Fried, R. L. (2001). The Passionate Learnerr: How teachers and parents can help children reclaim the joy of discovery. Boston, MA: Beacon Press.

Frijda, N. H., Mesquita, B., Sonnemans, J., \& Van Goozen, S. (1991). The duration of affective phenomena or emotions, sentiments and passions. In K. T. Strongman (Ed.) International review of studies on emotion. (pp. 187-225). New York: Wiley.

Goldberg, C. (1986). The interpersonal aim of creative endeavour. Journal of Creative Behavior, 20, 35-48.

Grohman, M. G., Ivcevic, Z., Silvia, P., \& Kaufman, S. B. (2017). The Role of Passion and Persistence in Creativity. Psychology of Aesthetics, Creativity, and the Arts. Advance online publication. http://dx.doi.org/10.1037/aca0000121

Hennessey, B. A., \& Amabile, T. A. (2010). Creativity. Annual Review of Psychology, 61, 569-598. http://dx.doi.org/10.1146/annurev.psych.093008.100416

Ho, V. T., Wong, S. S. (2011). A Tale of Passion: Linking Job Passion and Cognitive Engagement to Employee Work Performance. Journal of Management Studies, 48 (1), 26-47.

Hodgins, H. S., Knee, C. R. (2002). The integrating self and conscious experience. In R. M., Ryan, E.L. Deci (Eds.), Handbook of self-determination research. (pp. 87-100). Rochester, NY: University of Rochester Press.

Ivcevic, Z., \& Mayer, J. D. (2009). Mapping dimensions of creativity in the life-space. Creativity Research Journal, 21, 152-165. http://dx.doi.org/ 10.1080/10400410902855259 Karwowski, M. (2009). Klimat dla kreatywności. Koncepcje, metody, badania. [Climate for Creativity. Concepts, Methods, Research]. Warszawa: Difin. 
Karwowski, M. (2010). Kreatywność - feeria rozumień, uwikłań, powodów. Teoretycznoempiryczna prolegomena. [Creativity - variety of understandings, entanglements, reasons. Theoretical and Empirical prolegomenon]. In M. Karwowski, A. Gajda (Eds.). Kreatywność (nie tylko) w klasie szkolnej. [Creativity in a class]. (pp.12-44). Warszawa: APS.

Kaufman, B., \& Gregoire, C, (2015).Wired to Create: Unraveling the Mysteries of the Creative Mind. New York: Perigee.

Kaufman, J. C., \& Beghetto, R. A. (2009). Beyond Big and Little: The Four C Model of Creativity. Review of General Psychology, 13(1), 1-12.

Kaufman, J.C. (2003). Critical thinking, creativity, and culture: An introduction. Inquiry: Critical Thinking Across the Disciplines, 22(3), 5-7. http://dx.doi.org/10.5840/ inquiryctnews200322313

Kunat, B. (2017). „Dzielenie się czasem wolnym z uczniem” czyli o pracy nauczycieli $z$ pasją. [,Sharing a free time with a pupil” a Word on the work of teachers with passion]. In E. Dubas, A. Gutowska (Eds.) Time and Places in a Biography. Educational Aspects. [Czas i miejsca w biografii. Aspekty edukacyjne]. (pp. 155-165), Łódź: Ut.

Kunat, B. (2015a). Entuzjazm, zaangażowanie, konik, a może bzik... W poszukiwaniu znaczeń kategorii „pasja”. [Enthusiasm, engagement, fervor, hobby or maybe craze... In the search for the meanings of the category of 'passion']. Rocznik Pedagogiczny, 38, 155-165.

Kunat, B. (2015b). Pasja jako źródło twórczości codziennej człowieka. [Passion as a source of everyday creativity of human]. (pp.94-103). In J. Uszyńska-Jarmoc, B. Kunat (Eds.), Twórczość codzienna jako aktywność całożyciowa człowieka. [ Everyday creativity as a lifelong human activity]. Bialystok: „Trans Humana”.

Kunat, B. (2015c). Pasja jako kategoria badawcza - w świetle dualistycznego modelu R. J. Vallerand'a. [Passion as a research category - in the light of R.J. Vallerand's Dualistic Model]. Psychologia Wychowawcza, 8, 31-41.

Lafrenière, M.-A. K., St-Louis, A. C., Vallerand, R. J., \& Donahue, E. G. (2012). On the relation between performance and life satisfaction: The moderating role of passion. Self and Identity, 11(4), 516-530.

Lavigne, G. L., Forest, J., Crevier-Braud, L. (2012). Passion at work and burnout: A twostudy test of the mediating role of flow experiences. European Journal of Work and Organizational Psychology 21(4),518-546. doi: 10.1080/1359432X.2011.578390.

Liu, D., Chen, X. P., \& Yao, X. (2011). From autonomy to creativity: A multilevel investigation of the mediating role of harmonious passion. Journal of Applied Psychology, 96, 294-309. 
Lubart, T. I., \& Getz, I. (1997). Emotion, metaphor and the creative process. Creativity Research Journal, 10(4), 285-301.

Luh, D.-B., \& Lu, C.-C. (2012). From cognitive style to creativity achievement: The mediating role of passion. Psychology of Aesthetics, Creativity, and the Arts, 6(3), 282288. http://dx.doi.org/10.1037/a0026868

Mageau, G. A., \& Vallerand, R. J. (2007). The moderating effect of passion on the relation between activity engagement and positive affect. Motivation and Emotion, 31, 312-321. doi: 10.1007/s11031-007-9071-z

Mageau, G. A., Vallerand, R. J., Rousseau, F. L., Ratelle, C. F., \& Provencher, P. J. (2005). Passion and gambling: Investigating the divergent affective and cognitive consequences of gambling. Journal of Applied Social Psychology, 35, 100-118.

Modrzejewska-Świgulska, M. (2013). Twórczość codzienna jako zasób wspierający dobrostan ludzi. [Everyday creativity as a resource supporting human welfare]. In K. J. Szmidt, M. Modrzejewska-Świgulska (Eds.), Zasoby twórcze człowieka. Wprowadzenie do pedagogiki pozytywnej. [Creative resources of a human being. Introduction to positive pedagogy]. Łódź: UŁ.

Modrzejewska-Świgulska, M. (2015). Twórczość codzienna w teorii i praktyce. [ Everyday creativity in theory and practice] (pp.23-36). In J. Uszyńska-Jarmoc, B. Kunat (Eds.), Twórczość codzienna jako aktywność całożyciowa człowieka. [Everyday creativity as a lifelong human activity]. Bialystok: „Trans Humana”.

Moeller, J. (2014). Passion as concept of the psychology of motivation. Conceptualization, assessment, inter-individual variability and longterm stability (doctoral dissertation). Retrieved from http://www.dbthueringen.de/servlets/DerivateServlet/Derivate29036/DissJulia

Montijo, M. N., Mouton, A. R. (2016). Love for Frequent and Low Flow Activities in the United States and India. Creativity. Theories-Research-Applications, 3 (2), 379-407, doi: https://doi.org/10.1515/ctra-2016-0023

Nęcka, E. (2002). Psychologia twórczości. [Psychology of creativity]. Gdańsk: GWP

Parastatidou, I. S., Doganis, G., Theodorakis, Y., \& Vlachopoulo S. P. (2012). Exercising with Passion: Initial Validation of the Passion Scale in Exercise. Physical Education and Exercise Science,16, 119-134. doi: 10.1080/1091367X.2012.657561

Peterson, C., \& Seligman, M. E. P, (2004). Character strengths and virtues: A handbook and classification. New York, NY: Oxford University Press.

Phelps, P. H. \& Benson, T. R. (2012). Teachers With a Passion for the Profession. Action in Teacher Education, 34(1), 65-76. doi: 10.1080/01626620.2012.642289 http://dx.doi.org/10.1080/01626620.2012.642289 
Philippe, F., Vallerand, R. J., Lavigne, G. (2009). Passion does make a difference in people's lives: A look at well-being in passionate and non-passionate individuals. Applied Psychology: Health and Well-Being, 1, 3-22. doi:10.1111/j.17580854.2008.01003.x

Philippe, F. L., Vallerand, R. J., Houlfort, N., Lavigne, G., \& Donahue, E.G. (2010). Passion for an activity and quality of interpersonal relationships: The mediating role of emotions. Journal of Personality and Social Psychology, 98, 917-932.

Plucker, J. A., Beghetto, R. A., \& Dow, G. T. (2004). Why isn't creativity more important to educational psychologists? Potentials, pitfalls, and future directions in creativity research. Educational Psychologist, 39, 83-96. http://dx.doi.org/10.1207/ s15326985ep3902_1

Popek, S. (2015). O istocie i mechanizmach pasji. [On the essence and mechanisms of passion]. (pp.15-35). In M. Dudzikowa, M. Nowak (Eds.) O pasjach cudzych $i$ własnych - profesorowie. [On the passions of someone else's and their own - professors]. Lublin: Wydawnictwo KUL.

Rousseau, F. L., \& Vallerand, R. J. (2008). An examination of the relationship between passion and subjective well-being in older adults. International Journal of Aging and Human Development, 66, 195-212.

Runco, M. A. (2003). Education for creative potential. Scandinavian Journal of Educational Research, 47, 317-324.

Runco, M. A. (2004). Creativity. Annual Review of Psychology, 55, 657-687. http:// dx.doi.org/10.1146/annurev.psych.55.090902.141502

Runco, M. A. (2016). Commentary: Overview of Developmental Perspectives on Creativity and the Realization of Potential. In B. Barbot (Ed.). Perspectives on creativity development. New Directions for Child \& Adolescent Development, Development, 151, 97-109.

Ryan, R. M., \& Deci, E. L. (2000). Self-Determination Theory and the facilitation of intrinsic motivation, social development, and well-being. American Psychologist, 55, 68-78.

Ryan, R. M., \& Brown, K. W. (2003). We Don't Need Self-Esteem: On Fundamental Needs, Contingent Love, and Mindfulness. Psychological Inquiry, 14(1), 71-76.

Salles, A., Cohen, G. L., \& Mueller, C. M. (2014). The relationship between grit and resident well-being. The American Journal of Surgery, 207, 251-254.

Seligman, M. E. P. (2002). Authentic Happiness: Using the New Positive Psychology to Realize Your Potential for Lasting Fulfillment. New York: Free Press.

Shi, J. (2012). Influence of passion on innovative behavior: An empirical examination in Peoples Republic of China. African Journal of Business Management, 6(30), 8889-8896. 
Silvia, P. J., Christensen, A. P., \& Cotter, K. N. (2016). Commentary: The Development of Creativity-Ability, Motivation, and Potential. In B. Barbot (Ed.). Perspectives on creativity development. New Directions for Child \& Adolescent Development, 151, 111-119. doi: 10.1002/cad.20147

Sternberg, R. J., \& Lubart, T. I. (1996). Investing in creativity. American Psychologist, 51, 677-688. http://dx.doi.org/10.1037/0003-066X.51.7.677

St-Louis, A. C. \& Vallerand, R. J. (2015). A Successful Creative Process: The Role of Passion and Emotions, Creativity Research Journal, 27(2), 175-187, doi: 10.1080/10400419.2015.1030314

Szmidt, K. J. (2013a). Positive Pedagogy: Creativity - talents - wisdom coalesced. [Positive Pedagogy: Creativity - talents - wisdom coalesced]. In K. J. Szmidt, M. Modrzejewska-Świgulska (Eds.), Zasoby twórcze człowieka. Wprowadzenie do pedagogiki pozytywnej [Creative resources of a human being. Introduction to positive pedagogy]. Łódź: UŁ.

Szmidt, K. J. (2013b). Pedagogika twórczości. [Pedagogy of creativity].(drugie wydanie poszerzone), Gdańsk: Gdańskie Wydawnictwo Psychologiczne.

Szmidt, K. J. (2007). Pedagogika twórczości [Pedagogy of creativity]. Gdańsk: GWP.

Szmidt, K. J. (2010). ABC kreatywności. [ABC of creativity].Warszawa: Difin.

Tokarz, A. (2005). Dynamika procesu twórczego. [The dynamics of the creative process]. Kraków: UJ.

Vallerand, R. J. (2008). On the Psychology of Passion: In Search of What Makes People's Lives Most Worth Living. Canadian Psychological Association, 49(1), 1-13. Doi: $10.1037 / 0708-5391.49 .1 .1$

Vallerand, R. J. (2010). On passion for life activities: The Dualistic Model of Passion. In: M. P. Zanna (Ed.), Advances in experimental social psychology (pp. 97-193). New York, NY: Academic Press.

Vallerand, R. J., Blanchard, C. M., Mageau, G. A., Koestner, R., Ratelle, C. F., Leonard, M., et al. (2003). Les passions de l'ame: On obsessive and harmonious passion. Journal of Personality and Social Psychology, 85, 756-767.

Vallerand, R. J., Mageau, G. A., Elliot, A. J., Dumais, A., Demers, M. A., \& Rousseau, F. (2008). Passion and performance attainment in sport. Psychology of Sport and Exercise, 9, 373-392.

Vallerand, R. J., Paquet, Y., Philippe, F. L., \& Charest, J. (2010). On the role of passion in burnout: A process model. Journal of Personality, 78, 289-312. 
Vallerand, R. J., Rousseau, F. L., Grouzet, F. M. E., Dumais, A., \& Grenier, S. (2006). Passion in sport: A look at determinants and affective experiences. Journal of Sport and Exercise Psychology, 28, 455-478.

Vallerand, R. J., Salvy, S. J., Mageau, G. A., Elliot, A. J., Denis, P. L., Grouzet, F. M., \& Blanchard, C. (2007). On the role of passion in performance. Journal of Personality, 75, 505-534. doi: 10.1111/j.1467-6494.2007.00447.x

Vallerand, R. J., (2015). The Psychology of Passion. A Dualistic Model. New York, NY: Oxford University Press.

Von Culin, K., Tsukayama, E., \& Duckworth, A. L. (2014). Unpacking grit: Motivational correlates of perseverance and passion for long-term goals. Journal of Positive Psychology, 9, 306-312. doi:10.1080/17439760.2014.89832

Corresponding author at: Beata Kunat, Faculty of Pedagogy and Psychology, University of Bialystok, 20 Świerkowa St., 15-328 Bialystok, Poland.

E-mail: b.kunat@uwb.edu.pl 